\title{
Independence of Lawyers and Legal Institutions and Its Impact on the Country's Development
}

\author{
Ali Ravanan ${ }^{1}$, Leila Ghashghaei ${ }^{2} \&$ Gholam Reza Ghashghaei ${ }^{2}$ \\ ${ }^{1}$ Qom Branch, Islamic Azad University, Qom, Iran \\ ${ }^{2}$ Zahedan Branch, Islamic Azad University, Zahedan, Iran \\ Correspondence: Ali Ravanan, Phd. student Private law, Qom Branch, Islamic Azad University, Qom, Iran.
}

\author{
Received: February 14, 2016 Accepted: June 15, 2016 Online Published: June 29, 2016 \\ doi:10.5539/jpl.v9n5p24 \\ URL: http://dx.doi.org/10.5539/jpl.v9n5p24
}

\begin{abstract}
So far, have more written about lawyer, have less successful. Lawyer should be independent. Therefore, autonomy of Bar Association has been seriously proposed. Autonomy of judiciary and judges has always been emphasized in our constitutional law and has been proposed as judiciary should be separate of other powers. Judges shouldn't be dependent or under power of others. On the other hand, there is no comprehensive and sufficient reference in constitutional law about bar association and judge and power of attorney is considered under people rights. In spite of all emphasis, conception of this deduction is not clear. Attorney autonomy is rooted from various bases and has separate and specific conception other than judgment. Studying principles of constitutional law accurately shows that attorney occupation is not subject of any supervisor principle to judiciary, but just having lawyer in procedural process is a part of people rights. Therefore, law maker shouldn't see them equal to regulate constitutional law and pit attorney power as judgment under supervision of judiciary.
\end{abstract}

Keywords: bar association, lawyer autonomy, power of attorney, attorney history

\section{Introduction}

Lawyer autonomy and consequently bar association autonomy is a clear conception, but if this conception isn't analyzed by various aspects, may lead to cognitive mistake. First, we should know that bar associate is not western invention and is not an imported conception, but bar association in Islamic thought has principal and original root that this source can be the best field for accurate conception based on religion for having lawyer autonomy. Therefore, 2 main following aspects can be considered as conceptual introduction of attorney.

First speech, lawyer status and attorney origin is in religious hadith and reasoning. Lawyer in merciful Quran is used in one meaning as secure and pure to reflect attorney content means the best and most pure representation from one person to another to supply felicities of client to the best way. Moreover, God mentions the status of supporting others rights such as verse 58 of Nisa that search justice in verdicts and verse 38 of Hajj Surah that calls eminent God as supporter of believers. In many other verses, God is introduced as lawyer and deep conception of trust is on this basis. Lawyer as God feature means provider, protector, director, resourceful etc. in this regard, it can be stated that the real power of attorney is for God and in religious society lawyer can't forget this heavenly supporter and can't do whatever he desires.

Issue of attorney is so important in jurisprudence that religious scholars attributed a field to attorney in all jurisprudence books as "attorney field" (Note 1). Died Mohammad Javad Moghniyeh in the fifth volume of "Imam Jafar al-Sadiq law" book and said: attorney for jurisprudents is that one person delegate law by his power to another. In addition Ima Khomeini in "Tahrir Al-vasileh" said: attorney is to work for him as he is alive and cooperate with him. Died Saheb Javaher said: no problem is in legality of attorney contract, but it may be one of religion necessities that need argument. In addition to Quran and hadith, other reasoning such as four reasons implies that attorney is acceptable and legal.

According to previous texts, attorney with religious background can be defined different from its western definition, in monotheistic communities and heavenly religions especially Islamic society, intention to attorney is not just for material and this world affairs, but its main motivation and purpose is attention to God and spirituality. Belief in God and God orientation makes lawyer to act for rights of clients by faith to God and resurrection day. Therefore, in Islamic society, lawyer is required to know himself example of a faithful, believer, 
and honest person and knows servicing God subjects as his humanistic an Islamic responsibilities and seek God satisfaction.

The second proper speech here to evaluate lawyer autonomy is necessity of lawyer autonomy issue and internal conservational status of lawyers in Islamic Republic of Iran. According to what mentioned, particularly religious background of attorney in Iran Islamic country, an adopted system from Shia jurisprudence thought won't see lawyer as judge assistant, right protector, and justice seeker. If lawyer is defined in its accurate meaning, it will be known as one principle of criminal justice that Islamic Republic of Iran was established for this matter. Lawyers' autonomy doesn't mean knowing them stranger, but it means providing working privacy and union for them that assures taking steps in right and justice by certain supervisorial mechanisms.

\section{Legal Definition of Attorney}

According to article 656 of Civil Law, "attorney is signing a contract by which one part delegate another part to do his affairs." Consequently of attorney contract, lawyer do legal works instead of client. (Ibid, 213)

Therefore, according to definition by Civil Law about attorney, the following results are obtained in cognition features and nature of attorney occupation:

1) Results of signing attorney contract is delegating, it means client knows lawyer actions in legal matters as himself and client gives power to lawyer to seize by client name and account. Therefore, lawyer is a mediator in doing affairs and what he does is for client. It means accepted commitment by lawyer is imposed on client and if any benefit, will happen for client. (Katuzian, 1998: vol. 2/57)

2) Subrogation is in administrative and credit affairs: according to appearance of article 656, it seems that attorney may be "legal act" such as selling house, lease termination, and divorce or other material affairs to do for client such as contractor of the building or mapping to surgery and painting. Nonetheless, it should be accepted that subrogation is imaginable in affairs that are done intendedly with effects that change client legal status. Furthermore, parts of related matters to attorney are done just if they have correct meaning that subrogation is related to legal act. For example, it is written in article 662 that "attorney is given in affairs that client can do it himself. Lawyer should be one who is master in doing that affair." (Katuzian, 1997: 77)

Content of this article gets meaning when attorney is supervisor of legal act, because client capacity to seize his prosperities and lawyer capacity to do it is proposed just in these affairs. Moreover, executive power of lawyer to do legal act is not the only accuracy condition and its main benefit is seen in this assumption that client doesn't have material power of doing them.

In addition, articles 660 and 661 of Civil Law, even article 656 itself, doesn't attributed to legal act in defining attorney contract. For example it is written in article 656 that "attorney is a contract that one part aske delegate to another part." According to him, this written can appear in in any legal and material act and we learnt in jurisprudence science that appearance has authority and is not constrained to legal act. For example, it is written in article 660 "attorney may be absolute ad for all affairs of clients or be constrained for certain affairs". Here, all related affairs to clients are stated in details and even legislator has stated its applicability or for example it is written in article 661 of Civil Law that "if attorney is absolute, it will just related to managing client prosperities" in this article, legislator attend to the opposite conception of article, it means if attorney is for all affairs, lawyer doesn't have right for legal act such as selling etc. in addition, he confirmed that according to well-known definition "getting deputy for occupation" it is perceived that "legal capture", but as it was stated in jurisprudence definition about attorney, Although, Imamiyeh scholars have used "getting deputy for occupation", they never have limited occupation to legal acts and they know cases after death and hajj as exemplifiers of subrogation and even the world "order", "action", and "object" in definition of Imamiyeh definition. (Mousavi Al-Khomeini, 1996: vol. 2/34) and all indicate this fact that occupation is absolute and non-subrogating occupations are exceptional or that absolute gets limitation.

Dr. Adl in definition of attorney contract said that distinctive feature of this contact is "getting deputy for occupation". It means lawyer is deputy of client to do any act not only by client name, but also by his name. (Adl, 1973: 331)

It can be claimed by frequent mentions that giving subrogation in any subrogating act is possible both legal and illegal acts such as worship and material actions. If legal and illegal acts such as worship and material actions are non-subrogating are for this reason that they don't have ability and talent of subrogation; although, both parties don't have qualification of giving subrogation not because action is material, it is it possible to subrogate it. 


\section{Autonomy of Attorney Professional Organization}

Before agenda of $11 / 13 / 1919$, attorney at trial was not subject to certain provisions even to have professional organization for such jobs. It is written in this article that "to get peace of claimers and facilitation in their work, law will consider initially lawyer and then other necessary legislations gradually. Since title of attorney was not under specific regulations in the past, maybe it seemed unworthy in people minds, but not with legislation, each lawyer should have formal examination and necessary requirements and honors." (Shahbazi, 2011, 129)

Before working as lawyer, they knew jurisprudence regulations enough for attorney and knew any regulations from justice office denier of attorney and jurisprudence freedom. In jurisprudence, attorney in hostilities was written under attorney contract and anyone can be lawyer except in judgment and witness. For example, research Helli wrote in Sharaye Al-Ahkam: "four chapter is lawyer and he is valid when to be mature and intellect even he is unfaithful, infidel, or apostate. If a Muslim is lawyer and be spectate, his attorney isn't abolished, because being apostate doesn't prevent from attorney and being lawyer." And it is recommended lawyer have full wisdom and be intelligent on what he does and speech." (Helli, 1995: 326-327)

Eventually, attorney was assigned in article 58 in 1936 that a type of apparent, artificial, and autonomy was given to bar of association. Attention to articles 17 to 21 of this law refers to apparent convenience and cancelation independent and legal characteristics of bar of association: "Ministry of justice establishes bar of association wherever it knows necessary." "Bar off association is an institute with legal characteristics and independent according to incomes and costs and subordinate of ministry of justice according to regulations." Dr. Matin Daftari, minister of justice at February of 1937 selected the first board of managers according to this law and defend himself in very detailed lecture and announced philosophy of law article 1315 as description importance of lawyer Guild, definition of attorney procedures, and determination mission of bar of association. (Matin Daftari, 1999: 185)

After victory of Islamic Republic of Iran in January, 1978 and approval of Iran constitutional law, Iran legal system got changed deeply such as evolutions in constitution of judiciary and its autonomy from other powers. In this institute, in spite of other legal systems with detailed regulation in constitutional law, issue of bar of association didn't described explicitly and just referred to people rights in having lawyer services and referred to necessity of providing lawyer for who are not able to select lawyer (article 35). In addition, none of articles related to judiciary system and justice refers slightly to justice attorney and seems approval of removing attorney issue from judiciary and inevitably shows independent and autonomy of this profession from judiciary system.

Autonomy of bar of association is in investigating entering conditions to attorney profession, training trainees, and promoting training and teaching to lawyer permanently. This part of independency was emphasized in legal bill of justice bar association (part A-article 6, 7, and 8). Under provision of article 12 of getting license quality approved in 1997 that necessitated taking exam at least once a year and determined number of trainees in qualification of commission from Chief Justice of the province. In addition, article 187 of the third development plan for economic, social, and cultural rights, adopted on 2000 on the judiciary of the Islamic Republic of Iran allow graduates to be approved for licensing rights institutions for their legal advice act and consultants can participate in the court of justice and other governmental and nongovernmental agencies and organizations. (Shahkar, 1952: 39)

\section{Lawyer Autonomy}

The lawyer should clients only representative the proceedings. However, he has many roles that required his independence. Autonomy of lawyer had thus far about the independence of the Bar analyzed sent pursuant to ensure judicial independence, defense rights and the rule of law in society. The multiple roles of lawyers and numerous documents mentioned in the regulations, including the universal declaration of human rights act of 1948, noted that in article 10 the right to a fair and public proceeding in an independent and impartial court told: proceedings that need with access to "all guarantees necessary for the defense" to be held (article 11). All the guarantees necessary to defend itself sufficient to understand the role of the lawyer in these proceedings, because that lawyer cannot claim related to the investigation and prosecution and the defense as, but the justice of employee can get the money from the client act against him. In article 14 of the international covenant on civil and political rights 1966, the United Nations aimed at the rights of persons before the courts and the court of justice, it is important for this type of proceedings to be mentioned as one type. It was document that our country joined in 1968 and the approval process in the house when it was finished in 1972. Similar text in paragraph (c) part 3 of article 6 of the European convention of human rights act 1950 and paragraph of section 2 of article 8 of the American convention on human rights 1969 and paragraph (c) part 1 article 7 of the African charter of human rights Act 1981 is predicted to proceedings fair and one of its parts refers lawyer. Two continents of Asia 
and the Pacific region do not have such documents, but in parts of Asia and among Muslim countries, Islamic declaration of human rights adopted by the ministers of organization of Islamic conference in Cairo in 1980 in document called "Islamic declaration of human rights" adopted the main clause of article 19 in the universal declaration of human rights have all the guarantees of a fair trial the defense has pointed out: "the defendant is innocent until the sentence of a fair trial where all the guarantees for his defense to be established." (Ghahramani and Yousefi Mahalleh, 2003: 92)

Among the international documents, the document specifically the issue of the independence of lawyers and professional associations of lawyers investigated, "the basic principles of lawyers' that the Eighth United Nations Congress on the prevention of crime and the treatment of the offender was approved in 1990 and is famous Havana declaration. It was written the introduction of this fundamental text reads: "according to the fact that people born in the United Nations charter, inter alia, their determination to provide the conditions in which justice is accessible has been emphasized, and as one of the targets his achieve international cooperation in promoting and encouraging respect for human rights and fundamental freedoms without discrimination on race, sex, language and religion have declared, according to the universal declaration of human rights, the guardian of the principles of equality before the law, presumption of innocence, the right to a fair and public proceeding by an independent and impartial court, and benefit from all the guarantees necessary for any person charged with a criminal act of defense, in addition to the international covenant on civil and political right to broadcast trial without unjustified delay and the right to a fair and public proceeding by a competent court, made up of independent and impartial law speaks to the international covenant on economic, social, and cultural rights to the government's commitment to adapt charter to promote universal respect for and observance of human rights and freedoms referred to the proceeding, according to the set of principles for the protection of people under any form of detention or imprisonment provides that a detained person should have the right to aid counsel communicate or advice he is entitled, according to the standard minimum rules for the treatment of prisoners, in particular, gives advice that legal assistance and confidential communication with counsel should be provided for those who have not tried, as it guarantees the supporting people facing the death sentence reaffirmed the right of every person suspected or charged with a crime punishable by the death penalty may be appropriate to have legal assistance at all stages of the proceedings, in accordance with article 14 of the international covenant on civil and political rights, has stressed, Since the declaration of basic principles of justice for victims of crime and abuse of power recommends the adoption of arrangements to be in the national and international levels to provide access to justice and behavior, restore the situation, fair compensation and assistance for victims of crime done, with regard to the appropriate protection of human rights and fundamental freedoms of persons with respect to economic, social and cultural, or civil and political, requires that all persons enjoy the legal services provided all tailored to the needs and in partnership with government agencies and other public interests have a vital role to advance the goals of justice and the principles of lawyers, as the future, in order to assist member states in their duty to ensure the good for lawyers have been formulated, should state in the framework of their national legislation and practice respected and attention should also be considered and lawyers and other persons, such as judges, prosecuting authorities and members of the executive and legislation. Generally, principles for all of the people should also apply to legal persons engaged without being officially have a situation where it is appropriate to be applied." (Katuzian, 2012, 167)

Therefore, the lawyer must be independent to cope with this role handle. Which in the charter of the fundamental principles of European lawyers and European lawyers set of rules of professional conduct, the first in 2006 and second in 1988, the council of European has bar association and emphasized: "the number of tasks assigned to lawyers for his absolute independence, free from any pressure, especially the pressure of special interests or external pressures associated with them. The independence of the judiciary, such as self-confidence as well as to the impartiality of the judge is required. Therefore, lawyer should prevents any damage to his independence and be careful to please the client, the judge and the parties does not neglect in respect of professional conduct. This independence is necessary for legal work such as judicial activism. Consult a lawyer to the client if the flattery, for personal gain or as a result of external pressure has no value. "On this basis, the independence of lawyers is accompanied by the fact that he is free to accept or reject the proxy fight, the rest of the law or resign from it, unless the law prohibits it is to maintain honesty and integrity in client secrets overall (for the study of the legal approach to the concept of independence rf. Ghamami and Mohseni, 2011, p: 73- 68).

The settlement also requires that no lawyer can be suspended or barred from practicing law, but the final decision of the disciplinary court (article 17 of the act of independence), even if the applicant's lawyer, the minister of justice or the president of the bar association is suspended (article 18 of the law). The relationship between the executive and legislative counsel did not guarantee the independence of the judiciary and the 
relationship between the lawyer and the device guarantees the independence of judges. Independence of the bar who provide the defense rights and the rule of law, in important fields such as entering the legal profession, management of bar association and the rules of professional ethics and regulations required by the current state of our rights greatly undermined been sent. But the lawyer must be independent, unlike the independence of judgment, rooted in the numerous responsibilities and roles in the community he is responsible. (Mohseni, 2013: 66) Today lawyers only spent a representative of the parties, he seeks to monitor or enforce the law, justice, uphold the principles of equality before the law, presumption of innocence, the right to a fair and public proceeding by an independent and impartial court, and benefit from all the guarantees necessary for the defense of the accused in a criminal matter, fair trial, legal advice by persons imprisoned or sentenced to death, assistance to victims of crime. So, the lawyer must be independent to be able to cope with all role to handle. The Foundation is an independent law requires independent judgment.

\section{Analysis the Comprehensive Bill Texture of Formal Attorney about Lawyer Autonomy}

The clear implication of words, words, and phrases of the bill, as producer of the draft bill of the "lawyer", as the employment relationship is one of the three branches. Review this issue and taking it, requires the use of literary techniques such as content analysis is not. Once this bill is read enough articles to be revealed to anyone including expert and non-expert.

According to the provisions of this act, a lawyer at all stages from entry to retirement is no job security, defense and guarantee protection for fundamental rights and their natural and not natural.

A1: Article 26 provides that the following three topics:

"In order to review and comment and also for qualified candidates to obtain licenses to practice law supervision delegation of seven judges, lawyers and lawyers for a period of 4 years by the head of the judiciary are appointed, forms, which called the supervisory board. "

A 2: Article 30 of the bill provides:

"If the lack of competence of the supervisory board or deterioration in any of the lawyers or members of the Board of Directors to acquire a direction other than disciplinary offenses, his license is revoked."

\section{A 3: Under Article 38 of the bill:}

"Testing and inspection of their trainees' theoretical and practical aspects of the testing board consisting of three persons by a lawyer or judge the supervisory board appointed judiciary in article 25 and it is approved, will come into operation."

A 4: according to article 42 of the bill, even law license must be signed by the chief justice of Article 42 "licenses to practice law with the signature of the head of the chief justice of the province exported."

If the license was not issued proxy; more correctly not signed by the honorable chief justice, what will be the responsibility?

\section{Autonomy of Bar Association or Lawyers Guild Organization}

B (1): the same substance a bill is unclear and is not lost on that principle does not require belief in focus or organization independent lawyers is not an organization or institution that by the power of the honorable judiciary is formed inevitably and requirements of rational law and the will of ingredients cannot be independent is. That is why it is quite logical that article 5 of the bill and does not independent institution but to its credit it independent character.

B (2): the organization or institution in any of the structural and operational aspects is not independent because:

First, the jurisdiction of the board of directors by the supervisory board referred to in article 25 bill (board of seven appointed head of the judiciary) should be established.

Secondly, the supervisory board at any time and for any reason or no reason it can be said with the board have lost wholly or in part of its jurisdiction. Article 30 of the bill say: "If lack of competence of the supervisory board or decline it in any of the lawyers or members of the board shall acquire his license is revoked."

Thirdly, neither accepts nor recognizes the number of apprentice training required, not practical and scientific qualification of students and not the attorney licensing board or agency of the bar association's organs. Investigation of violations of law students and lawyers remain not the duty of lawyers is not available in other words, none of the functions and powers set forth in article 6 this bill by the board and the board itself is not. Paragraph 8 of article 21 of the absorbent determine the number of lawyers in the exclusive jurisdiction of the judiciary, as, approved by the board of scientific tests approved by the supervisory board of judges or lawyers 
(article 38 of the bill), issued and signed by the chief law license Justice of the province (article 42 of the comprehensive bill of law).

B (4): Association disciplinary court, organization or institution: the bill unfortunately what is required by an institution or agency of the Union - civil - public, professional or any other as neglected and it is quite deliberate:

First, a comprehensive bill of law laid down in Article 91 states: "military court and in general with any law court is formed. President of the court by the prosecutor that the judges have to offer at least basic legal 9 chief justice of the province and notified chief ironically every part determined."

Attorney military court of justice and the bar association should notify the judge he was employed as a prosecutor or law enforcement official organization lawyers association, issued by the honorable president of the judiciary?!!

Secondly, the disciplinary court of law court is the first instance and appeal.

It is not enough, but must be voted by the police court judge and two other members of the judiciary should be exported, only a lawyer who is a member of the advisory and have no validity and legal effect of them.

The disciplinary court of appeal on the basis of article 93 consists of five members, a chairman of a counselor and three members - chairman and adviser to the head of the judiciary and judges who elected them and three other members said that the absence of a lot of difference. There are lawyers and legal elected by the council as agreed under the same material as the two judges, two of the five members are sufficient for the decision and the verdict.

\section{Conclusion}

Obviously, the lawyer who can deny the phenomenon, the phenomenon, and concept of the modern era. As it happens, and justice in the current board and organized exactly individuation of the modern era and the political and legal theories such as the separation of powers and is consolidated. We find this phenomenon (law) to be judged by the actions of human God-given right to rule their own destiny.

Finally, the implementation of this approach and its results with the text "comprehensive bill of law" explicitly found that the drafters of the bill in all honesty, lack of belief in the necessity of defending independence and the independence of the bar is hidden or not and whatever that such a possibility is provided, has been high. It is a harvest and can be picked up or had picked up the other. But if what the constitution has to be considered, if necessary, inherent and essential details of the phenomenon and the law on judicial legal structure based on the constitution we note that if the legislative history of the provisions of international treaties and other documents and protocols of the UN and its institutions in mind.

The evolution of the law and the bar after the Islamic Revolution in a way that especially with the quality of the legal license of 1997 and article 187 of the third development plan, the monitoring of the bar and the bar of the judiciary increased the judiciary and the training of lawyers and legal consultants said that the custodian of the issuing and renewal of their licenses and handle violations of law and management executive board is installed. That fear increased independence of the bar association and lawyer. Recommended literature or solicitors bar association and the senate research center, the rest largely with the independence of the bar association as an independent civil institutions are not consistent to the extent that the lawyer may be predicted that when freedom and independence relies on the adherence of Islamic jurisprudence knew and was able to remain independent as a phenomenon of the former regime, the new rules, a function of the judiciary, its independence to lose. Which is moving backwards and could threaten people's rights to be mentioned in the constitutional law.

\section{References}

(1997). Civil Rights (certain contracts: 4). Tehran, Bahman Borna publishing company publishing partnership with Modarres. Danesh.

(1998). Civil Rights introductory period (Lessons from certain contracts) (Vol. 2). Tehran: Ganj

Adl, M. (1963). civil law. Tehran: Amir Kabir publication.

Ghahramani, N., \& Yousefi Mahalleh, E. (2003). total collection of attorney regulations. Tehran: Majd publication.

Ghazvini, M. A. (1993). Sighal Oghud val Igha'at, description by Mohammad Ali Gharache Daghi, Qom: Islamiyeh.

Helli, A. J. A. (1995). Sharaye Al-Eslam (Vol. 1 \&2, Edited by A. Ibn Ahmad Yazdi). Tehran: Tehran University 
Publication.

Ibn Manzur. (1984). Lessan Al-Arab (Vol. 11). Beirut: Dar Al-Ehya Al-Toras Al-Arabiyah.

Imami, S. H. (1993). Civil laws (Vol. 2). Tehran: Islamic book store.

Jaziri, A.-R. (2007). Alfegh Alal Mazaheb Arbaat (Vol. 3). Beirut: Daralfekr.

Johari Esmaeil, I. H. (1990). Sahhah (Vol. 5). Beirut: Dar Al-Malaein.

Katuzian, N. (2012). an introduction on law science and study in Iran legal system. Tehran: Enteshar corporate.

Matin Daftari, A. (2001). Civil and Commercial Procedure Code (Vol I). Tehran: Majd.

Merciful Quran, translated by Mehdi Elahi Ghomshei.

Mohseni, H. (2013). Advocacy and the Bar Association in legal systems. Tehran corporation Enteshar.

Mousavi Khomeini, R. (1996). Tahrir Alvasileh (Vol. 12). Qom: Nashr Islami.

Shahbazi, M. H. (2011). bases of permission and ability to refer to legal acts, Ph.D. thesis, Tehran University, political science department.

Shahkar, M. (1952). the independence of the Bar Association. the Bar Association magazine, (5).

Sorkhi, S. E. S. (2000). Almabsut (Vol. 10). Beirut: Saral Fekr.

\section{Note}

Note 1. Bab Al-Vekaleh.

\section{Copyrights}

Copyright for this article is retained by the author(s), with first publication rights granted to the journal.

This is an open-access article distributed under the terms and conditions of the Creative Commons Attribution license (http://creativecommons.org/licenses/by/3.0/). 